\title{
The role of climate change in regulating Arctic permafrost peatland hydrological and vegetation change over the last millennium
}

\section{Zhang, Hui}

2018-02-15

Zhang , H , Piilo , S R , Amesbury , M J , Charman , D J , Gallego-Sala , A V \& Väliranta , M M 2018 , ' The role of climate change in regulating Arctic permafrost peatland hydrological and vegetation change over the last millennium ', Quaternary Science Reviews , vol. 182 , pp. 121-130 . https://doi.org/10.1016/j.quascirev.2018.01.003

http://hdl.handle.net/10138/307634

https://doi.org/10.1016/j.quascirev.2018.01.003

cc_by_nc_nd

acceptedVersion

Downloaded from Helda, University of Helsinki institutional repository.

This is an electronic reprint of the original article.

This reprint may differ from the original in pagination and typographic detail.

Please cite the original version. 
1 The role of climate change in regulating Arctic permafrost peatland

2 hydrological and vegetation change over the last millennium

3

$4 \quad{ }^{1 *}$ Hui Zhang, ${ }^{1}$ Sanna R. Piilo, ${ }^{2}$ Matthew J. Amesbury, ${ }^{2}$ Dan J. Charman, ${ }^{2}$ Angela V. Gallego-Sala, ${ }^{1}$ Minna

5 M. Väliranta

$6 \quad{ }^{1}$ ECRU, Department of Environmental Sciences, University of Helsinki, P.O. Box 65, 00014, Finland

$7 \quad{ }^{2}$ Geography, College of Life and Environmental Sciences, University of Exeter, UK

8 *Corresponding author: Email: hui.palaeo@gmail.com

10 Abstract

11 Climate warming has inevitable impacts on the vegetation and hydrological dynamics of high-latitude

12 permafrost peatlands. These impacts in turn determine the role of these peatlands in the global

13 biogeochemical cycle. Here, we used six active layer peat cores from four permafrost peatlands in

14 Northeast European Russia and Finnish Lapland to investigate permafrost peatland dynamics over the

15 last millennium. Testate amoeba and plant macrofossils were used as proxies for hydrological and

16 vegetation changes. Our results show that during the Medieval Climate Anomaly (MCA), Russian sites

17 experienced short-term permafrost thawing and this induced alternating dry-wet habitat changes

18 eventually followed by desiccation. During the Little Ice Age (LIA) both sites generally supported dry-

19 hummock habitats, at least partly driven by permafrost aggradation. However, proxy data suggest that

20 occasionally, MCA habitat conditions were drier than during the LIA, implying that evapotranspiration

21 may create important additional eco-hydrological feedback mechanisms under warm conditions. All sites

22 showed a tendency towards dry conditions as inferred from both proxies starting either from $c a .100$

23 years ago or in the past few decades after slight permafrost thawing, suggesting that recent warming has

24 stimulated surface desiccation rather than deeper permafrost thawing. This study shows links between

25 two important controls over hydrology and vegetation changes in high-latitude peatlands: direct

26 temperature-induced surface layer response and deeper permafrost layer-related dynamics. These data

27 provide important backgrounds for predictions of Arctic permafrost peatlands and related feedback

28 mechanisms. Our results highlight the importance of increased evapotranspiration and thus provide an

29 additional perspective to understanding of peatland-climate feedback mechanisms.

\section{Keywords}

32 Testate amoeba, plant macrofossil, hydrology, vegetation, permafrost peatlands, last millennium, MCA,

33 LIA, recent warming 
36 High-latitude peatlands play a critical role in the global biogeochemical cycle, through which they also contribute to climate dynamics (Frolking and Roulet, 2007). Temperature and moisture balance are key factors modulating peat accumulation (Carroll and Crill, 1997; Davidson and Janssens, 2006; Ovenden, 1990). Global warming, especially amplified warming in high-latitude regions (IPCC, 2013), is expected to directly stimulate photosynthesis and net primary productivity (NPP) in high-latitude ecosystems because of increased growing season length (Charman et al., 2013). Thus, peat accumulation is expected to accelerate too (Loisel and Yu, 2013). However, higher temperatures also increase peat decomposition rates through accelerated microbial activity (Dorrepaal et al., 2009; Ise et al., 2008), yet there is evidence from the past that during warm periods the increase in NPP exceeded the potential increase in decomposition (Charman et al., 2013). Climate scenarios for high latitudes predict that mean summer precipitation will increase in the future (Collins et al., 2013), which could be beneficial for peat accumulation. However, increases in precipitation may be offset by increases in evapotranspiration under higher temperatures (Yu et al., 2009). Also, seasonal droughts may reduce NPP and increase decomposition (Yu et al., 2009). Moreover, habitat-specific plant functional types (PFTs) that characterise different peatlands (fens and bogs) have different NPP dynamics and the distribution of these communities can exert a control on peat accumulation patterns (Tuittila et al., 2012). While climate may directly affect plant productivity and decomposition, it may also have larger-scale impacts on the geographical distribution of peatland types (Väliranta et al., 2015).

54 Arctic permafrost peatlands are sensitive to climatic changes (Gałka et al., 2017a; Lamarre et al., 2012; Swindles et al., 2015a; Teltewskoi et al., 2016; Tremblay et al., 2014) and at the same time, they affect local microclimate, hydrology, vegetation, peat and carbon accumulation and these non-climatic factors again influence the degradation and aggradation of permafrost (Zuidhoff and Kolstrup, 2000). Due to pronounced microtopography and persisting ice, eco-hydrological processes and therefore peat accumulation patterns in permafrost peatlands are very complex (Oksanen, 2006; Oksanen et al., 2001), making the evaluation of climate change impacts on these environments challenging. Northern

61 Hemisphere mean annual temperature for the last 30- and 50-year periods is likely higher than any other 62 preceding equally long measurement period during the past 800 years (Masson-Delmotte et al., 2013).

63 Permafrost ground temperature monitoring studies have documented a rising trend over the last 20-30 64 years and observations suggest permafrost thaw in the southern margins of the permafrost area (Brown and Romanovsky, 2008; Johansson et al., 2011; Sannel et al., 2016). Even though these observations are not ubiquitous (Brown and Romanovsky, 2008), a widespread permafrost thaw can be expected as a 
consequence of global warming. It may be speculated that Arctic permafrost peatlands are on the edge of their climatological niche and have low potential to remain stable under future climate changes (Bosio et al., 2012). One presumption is that when permafrost thaws or if the active layer deepens considerably, permafrost areas become large $\mathrm{CO}_{2}$ sources due to accelerated decomposition rates (Abbot et al., 2016;

71 Koven et al., 2011; Schadel et al., 2016). It is suggested that these dynamics may be one of the most significant potential feedbacks from terrestrial ecosystems to the atmosphere in the future (Schuur et al., 2008). However, because of the scarcity of information and data, disentangling the links between permafrost peatland vegetation, hydrology and climate, the future balance of NPP and decomposition processes in permafrost peatlands has remained uncertain. These coupled dynamics can be investigated by comparing palaeoecological data to documented climate epochs such as the Medieval Climate Anomaly (MCA) from $c a$. AD 950-1200, the Little Ice Age (LIA) from $c a$. AD 1400-1850, and recent warming since the late $19^{\text {th }}$ century (e.g., Cook et al., 2004; Esper et al., 2002; Hanhijärvi et al., 2013; Wilson et al., 2016). In this study we investigated past hydrological changes and associated variations in vegetation composition during the last millennium in four permafrost peatlands. We used two different proxies; testate amoebae (Amesbury et al., 2016; Charman et al., 2007; Swindles et al., 2015b) and plant macrofossils (Väliranta et al., 2007; 2012) to reconstruct past moisture conditions and vegetation history, which enabled cross validation of results and therefore more dependable data interpretation (Loisel and Garneau, 2010; Väliranta et al., 2012). Using ${ }^{14} \mathrm{C}$ and ${ }^{210} \mathrm{~Pb}$ dating, we linked detected changes to known climate periods. Replicate records from the same peatland and/or close-by regions allowed us to evaluate whether detected changes were climate-driven and regional or forced by autogenic factors (Mathijssen et al., 2016; 2017; Swindles et al., 2012). Our hypotheses were 1) that permafrost thawing triggered by warm climate conditions (e.g., MCA and recent warming), is reflected in proxy records as a change towards wetter plant communities and more hydrophilic testate amoeba assemblages, and that 2) permafrost aggradation under colder climate conditions such as LIA results in dry conditions through raising of the peat surface. Furthermore, we evaluate whether and how the peatland response to MCA warming differs from the on-going recent warming.

\section{Study sites}

96 Our four study sites are located in two regions: two sites (Indico and Seida) are located in the discontinuous permafrost zone of Russia whereas the other two (Kevo and Kilpisjärvi) are in the sporadic permafrost zone of the Finnish Lapland (Fig. 1 and Table 1). 
two peatlands are elevated a few metres from the surrounding mineral soil and the vegetation is

101 dominated by shrub-lichen-moss communities, such as Betula nana, Rhododendron tomentosum,

102 Empetrum nigrum, Sphagnum fuscum, Polytrichum strictum, S. lindbergii and sedges Eriophorum spp.

103 Compared to Seida, Indico presents extensive areas covered by lichens and mosses with a lower shrub

104 layer. Large bare peat surfaces occur on both sites (Repo et al. 2009).

105 At the two sites in Finnish Lapland, Kevo and Kilpisjärvi, the peatlands are characterised by separate

106 permafrost mounds a few metres high and surrounding wet flarks. The mound vegetation is dominated

107 by dwarf shrubs, such as Betula nana, Empetrum nigrum, Rubus chamaemorus and bryophytes

108 Polytrichum strictum and Dicranum spp. Different Sphagnum species such as S. fuscum, S. balticum, S.

109 majus and S. riparium occur along a hydrological gradient from dry hummock to wet hollow and

110 Eriophorum spp. are also present.

112 Materials and methods

113 Sampling

114 In total, six active layer peat cores (Table 1) were collected from the four permafrost peatland sites using

115 a Russian peat corer with a diameter of $5 \mathrm{~cm}$. In Indico, three replicate peat cores (Ind1-3) were collected

116 along a transect from the centre to the margins of the site to assess potential differences in sensitivity

117 across the peatland surface. A single core was collected from each of the other sites. Individual cores

118 were wrapped in plastic and transported to the laboratory in sealed PVC tubes and stored in a freezer.

119 The cores were later defrosted and sub-sampled in 1-cm or 2-cm thick slices for further analyses. In some

120 cases, analysis of both proxies from the same sample was not possible due to a lack of material. When

121 this occurred, analysis was carried out using stratigraphically adjacent samples. In core 'Sei' from Seida

122 the limited amount of material meant that only testate amoeba analysis was possible.

\section{Chronology}

125 Eighteen bulk peat samples were sent to the Finnish Museum of Natural History (LUOMUS, Helsinki,

126 Finland) and the Poznan Radiocarbon Laboratory (Poznan, Poland) for accelerator mass spectrometry

127 (AMS) ${ }^{14} \mathrm{C}$ dating (Table 1). Bulk peat samples were used because of high decomposition of some peat

128 sections, which made picking out known macrofossils very difficult or impossible. Additionally, a recent

129 study suggested that there is no significant difference between ages derived from bulk material and plant

130 macrofossils in these settings (Holmquist et al., 2016). The chronology of the top parts of three peat cores

131 were determined using ${ }^{210} \mathrm{~Pb}$ dating (Table 1). The samples were processed at the University of Exeter,

132 UK. A dry ca. 0.2-0.5 g subsample from each 1-cm interval was analyzed for ${ }^{210} \mathrm{~Pb}$ activity after spiking 
133 with a ${ }^{209}$ Po yield tracer. The procedure followed a modified version of Ali et al. (2008).

134 An age-depth model for each core was developed using CLAM 2.2 (Blaauw, 2010) in R version 3.2.4 (R

135 Core Team, 2014), with ${ }^{14} \mathrm{C}$ ages internally calibrated using the INTCAL 13 calibration curve (Reimer 136 et al., 2013). ${ }^{210} \mathrm{~Pb}$ ages were obtained through the Constant Rate of Supply model (CRS) (Appleby and

137 Oldfield, 1978), which was chosen over the Constant Initial Composition model because there was a

138 subsurface maximum in ${ }^{210} \mathrm{~Pb}$ activity in these three cores, suggesting that the peat accumulation rate has 139 not been constant over time. Both ${ }^{14} \mathrm{C}$ and ${ }^{210} \mathrm{~Pb}$ dates were included in the final age-depth models (Fig.

140 2). A smooth spline method was selected to develop the age-depth models with the exception of core Kev

141 BS, which yielded age reversals when the default smoothing parameter 0.3 of CLAM model was

142 employed and relatively large deviations of the calibrated ${ }^{14} \mathrm{C}$ dates to the age-depth model curve when

143 changing this parameter, so a linear interpolation method was used instead for that core. Calibrated

144 radiocarbon ages were rounded to the nearest 5 years. Negative ages indicate post-bomb ages (i.e. -50

145 cal. $\mathrm{BP}=\mathrm{AD} 2000$ ). In this study we focused solely on the time period of the last millennium.

147 Testate amoeba and plant macrofossil analysis

148 Testate amoeba sample preparation procedure followed a modified version of Booth et al. (2010).

149 Samples were boiled in distilled water for 15 minutes. Samples were sieved using a $180-\mu$ m mesh 150 instead of the standard 300- $\mu$ m mesh as some materials contained a large quality of decomposed plant 151 detritus. All samples were back-sieved using a 15- $\mu$ m sieve. Materials retained on the $15 \mu \mathrm{m}$ sieve were 152 centrifuged at $3000 \mathrm{rpm}$ for 5 minutes. 50-100 individual testate amoeba shells for each sample were 153 counted and identified to species level or 'type' under a light microscope with 200-400× magnification. 154 Taxonomy followed Charman et al. (2000), but occasionally online sources were used to aid 155 identification (http:/www.arcella.nl/; $\quad$ user.xmission.com/ psneeley/Personal/FwrPLA.htm).

156 Occasionally the lower parts of the peat sections were highly decomposed and decomposed plant material 157 hindered testate amoeba identification. These samples were treated with $5 \% \mathrm{KOH}$ to disaggregate and 158 remove fine organics before sieving (Barnett et al., 2013; Charman et al., 2010). However, because the 159 test count did not reach 50 specimens in these deeper samples, they were not included in the water-table 160 depth (WTD) reconstructions.

161 For plant macrofossil analysis, volumetric samples $\left(2-5 \mathrm{~cm}^{3}\right)$ were gently rinsed under running water 162 using a 140- $\mu \mathrm{m}$ sieve. No chemical treatment was necessary. Remains retained on the sieve were 163 identified and proportions of different plant types were estimated using a stereomicroscope. Further 164 identification to species level was carried out using a high-power light microscope following Väliranta 165 et al. (2007). In addition to identifiable plant remains, the proportion of unidentified organic matter 
(UOM) was also estimated.

WTD reconstruction

169 Testate amoeba WTD reconstructions were performed using the Rioja package (Juggins, 2015) in R 170 version 3.2.4 (R Core Team, 2014). The modern training set contained 59 testate amoeba taxa from 145 171 samples collected from the same study sites (Zhang et al., 2017). A tolerance-downweighted weighted 172 averaging with inverse deshrinking based model was applied and $\mathrm{z}$ scores of the reconstructed WTD 173 values were then calculated over the total length of all the cores to illustrate hydrological changes ( $\mathrm{z}>0$ 174 indicates drier than average conditions and $\mathrm{z}<0$ indicates wetter than average conditions; $\triangle \mathrm{z}=1$ 175 represents $8.14 \mathrm{~cm}$ WTD range in our dataset), as the reconstructions may poorly represent actual 176 magnitude of water table changes (Swindles et al., 2015c). Model testing and validation are discussed in 177 Zhang et al. (2017).

\section{Results}

180 Chronology and vertical peat growth

181 Age-depth models show that peat accumulation rates have not been consistent between the study sites 182 over the last few millennia (Fig. 2, Table 1). The thickness of active layers in four sites ranged from 31 $\mathrm{cm}$ to $45 \mathrm{~cm}$ and basal ages of active layers ranged from 1485 to $7230 \mathrm{cal}$. BP. In most cases, $25-30 \mathrm{~cm}$

184 peat thickness covered the last millennium, except in Seida where only $7 \mathrm{~cm}$ of peat has accumulated 185 during the last millennium. Mean peat accumulation rates over the last millennium ranged from 0.10 to $1860.81 \mathrm{~mm} /$ year. Vertical growth has been slower at Seida and Kilpisjärvi when compared to Indico and Kevo.

\section{Testate amoeba assemblages and reconstructed WTD}

190 In total, 35 testate amoeba taxa were found in the four study sites. The most dominant taxa for all sites 191 were Difflugia pristis, Pseudodifflugia fulva type, P. fascicularis type and Trigonopyxis minuta type (Fig. 192 3). In Indico Archerella flavum, Cyclopyxis arcelloides type, D. pulex, Hyalosphenia minuta and Nebela 193 militars type were also occasionally abundant, while in Seida Assulina muscorum, C. arcelloides type 194 and Trinema/Corythion type were present abundantly. In Kevo Trinema/Corythion type was dominant in 195 the topmost samples while in Kilpisjärvi the samples were dominated by Arcella catinus.

196 Three cores were analysed from Indico (Ind1-3), Russia. The testate amoeba assemblages of core Ind1 197 (Fig. 3a) were first dominated by P. fulva type and D. pristis at 985 cal. BP. After that until ca. 445 cal. 198 BP P. fulva type was the most abundant. Between ca. 445 and -30 cal. BP, P. fulva type, P. fascicularis 
type and C. arcelloides type were dominant. A. flavum and A. seminulum were frequently encountered in samples before -58 cal. BP, after which the proportion of $H$. minuta increased. WTD reconstructions showed that wet conditions occurred at 985 cal. BP, after which relatively dry conditions persisted, with only slight fluctuations before $c a$. $10 \mathrm{cal}$. BP. At $c a$. $10 \mathrm{cal}$. BP, a change from dry to wet conditions was detected. After a $c a$. 50-year wet phase, a gradual transition from wet to dry occurred.

The bottom part of core Ind2 (Fig. 3b) was a mixture of peat and sand and testate amoeba were absent or scarce, so testate amoeba data were available only from $c a .430$ cal. BP onwards. The assemblages were dominated by $C$. arcelloides type and P. fulva type between $c a .430$ and 10 cal. BP but towards the core surface $N$. militars type became the dominant taxon. WTD reconstructions showed a dry-wet shift at $c a .175$ cal. BP and a wet-dry shift at $c a .0$ cal. BP. During the period 175-0 cal. BP, conditions were generally wet, but fluctuating. Since $c a .0 \mathrm{cal}$. BP an obvious drying trend prevailed.

In core Ind3 (Fig. 3c), D. pulex and P. fulva type dominated the assemblages between $c a .1020$ and 211950 cal. BP. Then T. minuta type became abundant until ca. 490 cal. BP after which D. pristis and A. 212 flavum were the most abundant taxa until ca. 215 cal. BP. After that, D. pristis, N. militars type and T. 213 minuta type were the most common taxa. The WTD reconstruction showed very dry conditions prevailed 214 until ca. 400 cal. BP, when an obvious dry to wet shift occurred. However, the dominance of the medium 215 wet indicator D. pristis (Zhang et al., 2017) suggests only relatively wet conditions. Starting from this 216 shift, a slight wet to dry trend persisted until present-day.

217 At Seida (Fig. 3d), testate amoeba assemblages around 1060 cal. BP were dominated by P. fulva type, 218 while between $c a$. 1060 and 350 cal. BP D. pristis and A. muscorum were the most abundant taxa. 219 Relatively wet conditions were inferred between $c a$. 650 and 350 cal. BP and after $350 \mathrm{cal}$. BP, $A$. muscorum, C. arcelloides type and Trinema/Corythion type were the dominant taxa. WTD 221 reconstructions indicated that this site was persistently dry.

222 At Kevo (Fig. 3e), the assemblage was dominated by P. fulva type for the period ca. 1140-100 cal. BP, 223 then T. minuta type and T. arcula type became abundant between $c a$. 100 to $-20 \mathrm{cal}$. BP. Towards the 224 surface, T. minuta type together with Trinema/Corythion type were the most abundant taxa. WTD 225 reconstructions showed that dry conditions existed through the core with a relatively wet event recorded 226 at $c a .550$ cal. BP. A drying trend prevailed from $c a$. 50 cal. BP until present.

227 At Kilpisjärvi (Fig. 3f), the assemblages generally resembled those of Kevo but the timing of comparable 228 assemblage change differed. D. pristis, P. fulva type and $P$. fascicularis type were abundant between $c a$. 2291080 and 450 cal. BP. Large proportions of D. pristis and T. minuta type were recorded between $c a .450$ 230 and 0 cal. BP, with A. catinus and T. minuta types dominant towards recent times. Interestingly, some 231 samples $(18-23 \mathrm{~cm})$ contained large quantities of diatoms including taxa such as Pinnularia major, 
233 diatoms was so overwhelming that testate amoeba could not be reliably counted or identified, so these

234 samples were omitted from the WTD reconstruction. WTD reconstructions suggested a relatively wet phase $c a .650-450$ cal. BP after which, dry but slightly fluctuating conditions persisted until the present.

Vegetation, presence of permafrost and microtopographical evolutions

238 Plant assemblages varied between the cores (Fig. 3). Plant composition data were used to classify the contemporary habitat conditions and to infer the presence/absence of permafrost (e.g., Oksanen, 2006; Pelletier et al., 2017). In general, we interpret that communities dominated by sedges and brown mosses

241 indicate permafrost-free/thaw habitats while highly decomposed peat with ericaceous/woody remains 242 sometimes accompanied by lichens and fungi sclerotia indicate peat accumulated on top of permafrost

243 following the up-heave of the peatland surface. Though in general Sphagna assemblages are used to shed 244 light on moisture conditions they can also help to identify the presence or absence of permafrost.

245 Temporal permafrost melt may create suitable conditions for wet Sphagna but these species may also

246 represent permafrost-free hollow conditions. Dry Sphagna may grow on top of permafrost hummocks, 247 but equally on permafrost-free hummocks. In addition, though sedges are considered non-permafrost 248 species, some species such as Eriophorum spp. can grow on peat plateaus, thus more than a single 249 indicator is usually needed to identify potential presence of permafrost.

250 At Indico, between 1300 and 985 cal. BP, hummock shrub vegetation dominated in Core Ind1 (Fig. 3a), 251 probably indicating presence of permafrost. At around $985 \mathrm{cal}$. BP abundant sedge remains indicate wet 252 conditions, which in turn suggest permafrost free conditions, i.e. permafrost melting. After this, until ca. 25310 cal. BP, a mixed sedge-shrub phase, accompanied by fungi sclerotia, prevailed and peat was highly 254 decomposed. These together suggest re-establishment of permafrost. From $c a$. 10 to -40 cal. BP, a wet 255 hollow phase, dominated by S. majus and Warnstorfia spp., occurred and this might indicate temporary 256 melting of permafrost. This wet phase was followed by hummock conditions with S. fuscum, suggesting 257 permafrost re-aggradation. Ind2 (Fig. 3b) had a similar succession history, yet the timing differed. A highly decomposed 259 Ericales stage with presence of fungi sclerotia between 1725 and 175 cal. BP was followed by 260 Eriophorum vaginatum dominated phase at $c a$. 175 cal. BP. After that, a wetter lawn stage dominated by 261 S. rubellum prevailed until $\mathrm{ca} .30 \mathrm{cal}$. BP. This pattern suggests alternating permafrost aggradation and 262 melting. Similarly, the near-surface layers were dominated by S. fuscum, indicating permafrost reestablishment.

264 Ind3 (Fig. 3c) vegetation succession differed from the other two Indico records. A highly 
265 decomposed Ericales stage occupied peat layers dated to $c a$. 1020-880 cal. BP suggesting hummock 266 conditions on top of permafrost. Interestingly, after $880 \mathrm{cal}$. BP there was a community shift where

267 Ericales were replaced by other hummock communities, now dominated by S. fuscum. This phase lasted until ca. 235 cal. BP. Due to a limited amount of material, we have no continuous plant macrofossil data for the time-window from 215 cal. BP to present day (-52 cal. BP). Currently dwarf shrubs Ericales grow

270 at the coring location.

271 At Kevo (Fig. 3e), a mixed sedge-shrub vegetation characterised the entire peat core, suggesting that no major hydrological changes have taken place in the recent past. However, after $c a .380 \mathrm{cal}$. BP the plant mixture was accompanied by lichens probably suggesting permafrost conditions.

274 At Kilpisjärvi (Fig. 3f), before $c a$. 790 cal. BP sedges were the most dominant taxa but occasionally

275 accompanied by other taxa such as Bryophyta spp. This community suggests a typical permafrost-free 276 fen. The short period between $c a .790$ and 550 cal. BP was dominated by hummock species $S$. fuscum. 277 The following stage, which started at $c a .550 \mathrm{cal}$. BP and lasted until present was dominated by Ericales 278 spp. and indicated relatively stable hummocky conditions on top of permafrost.

\section{Discussion}

281 MCA-induced permafrost thaw and desiccation

282 In NE European Russia, extensive regional-scale permafrost aggradation occurred from $c a$. 2200 cal. BP 283 onwards (Hugelius et al., 2012; Routh et al., 2014). Therefore, we should be able to detect potential 284 MCA-induced permafrost dynamics and hydrological changes in our Russian cores. Our records suggest 285 that at first, the MCA warming resulted in permafrost melting and consequent establishment of fen-type communities or Sphagnum, which corresponds to previous European Russian studies (Routh et al., 2014). At Indico (Ind1) there was a vegetation change from shrub vegetation to sedges, corresponding with the wet conditions reconstructed from testate amoebae (Figs. 3a and 4). Core Ind3 shows a transition from shrub community to S. fuscum at ca. 900 cal. BP. (Figs. 3c and 4). This kind of Sphagnum establishment

290 has been proposed to be a result of warming and altered peatland hydrology and chemistry (Loisel and

291 Yu, 2013). However, here the relatively dry conditions implied by S. fuscum contrasts our first hypothesis, 292 possibly due to only partial permafrost thaw. Wet communities were replaced by shrub communities and 293 supported by testate amoeba reconstructed dry conditions which prevailed for the latter part of the MCA 294 (Figs. 3a and 3c). This phenomenon may either result from melt water drainage (Wilson et al., 2017), or 295 be caused by increased evaporation (Swindles et al., 2015a).

296 In Fennoscandia, our results suggest that Kevo and Kilpisjärvi peatlands stayed permafrost free until ca. 297600 cal. BP (see also Oksanen 2006). During the MCA, a relatively dry habitat prevailed at Kevo, while 
at Kilpisjärvi a wet fen prevailed (Figs. 3e and 3f). Interestingly, the samples from Kilpisjärvi dated $c a$. 970-630 cal. BP contained large amounts of diatoms and chronologically this clearly wet phase corresponds to a diatom bloom event reported from a northern Swedish peatland (Kokfelt et al., 2009; 2016). Kokfelt et al. (2016) suggested that this wet phase was likely due to the Samalas volcanic eruption in AD 1257 (693 cal. BP) and consequent acid deposition, which resulted in changes in vegetation. At around 790 cal. BP, S. fuscum established at the expense of previous rich fen plant communities and this was possibly triggered by volcanic impact rather than permafrost aggradation. However, none of the other peat sections analyzed for this study have diatom-rich layers or conspicuous plant community or moisture shifts dated to around the time of the eruption. During this time period typically dry shrubby conditions prevailed in the other sites, which may have been less sensitive to acid deposition.

\section{LIA-induced permafrost aggradation and drying}

310 In NE European Russia, in line with our second hypothesis, plant data suggest relatively stable dry

311 hummocky habitats during the LIA, whereas testate amoeba data mainly indicate dry conditions, with

312 occasional wet phases (Figs. 3 and 4). The discrepancies between the two proxies suggest testate amoeba 313 are more sensitive to environmental changes than plant communities (Gałka et al., 2017b; Loisel and 314 Garneau, 2010; Väliranta et al., 2012). These synchronous wet shifts in testate amoeba records at around $315450-400$ and 175 cal. BP (Fig. 4) contradict our second hypothesis of dry LIA conditions. However, the 316 timing of wet phases corresponds to many other wet records registered, for example, in parts of northwest 317 and central Europe (Charman et al., 2006; Gałka et al., 2014; Väliranta et al., 2007). These climate318 caused wet interruptions failed to trigger vegetation changes with the exception of the Ind2 record, which 319 showed a plant community change from shrubs to sedges dated to c. $175 \mathrm{cal}$. BP. This possibly suggests 320 a greater sensitivity of peatland margins to environmental changes, as core Ind2 was collected from a 321 more marginal location than Ind1 and 3.

322 Unlike at Indico and Seida, the beginning of LIA at Kilpisjärvi and Kevo seems to have been wet, which 323 corresponds to the humid climate recorded in other parts of Finland (Väliranta et al. 2007 and references 324 therein). Consistent with our second hypothesis, conditions subsequently shift and remain dry for the rest 325 of the LIA ca. 550-100 cal. BP, most evident in testate amoeba records. Plant macrofossil data from 326 Kilpisjärvi also support this shift by showing a vegetation change from Sphagnum domination to a dwarf 327 shrub community, whilst at Kevo the drying reflected by testate amoeba data failed to cause clear vegetation changes (Figs. 3e and 3f). In contrast, according to previous studies from Kevo (e.g., Oksanen

329 2006), LIA triggered permafrost initiation led to dry elevated peat surfaces and vegetation changes, 330 highlighting that one single peat core sometimes cannot capture a comprehensive regional story 
331 (University of Leeds Peat Club 2017). At Kilpisjärvi, a marked change to dry conditions indicated by 332 testate amoeba records happened around $175 \mathrm{cal}$. BP but this is absent at Kevo. This dry phase contrasts 333 the wet shifts at Indico and Seida, suggesting that the drivers of these changes were more regional in 334 scale.

\section{Implications of recent warming}

337 Interestingly, our data consistently suggest a habitat change towards drier communities in recent decades, contradicting our first hypothesis that warming results in wetting. The drying is reflected as a change from wet Sphagna to dry Sphagna (Ind1 and 2), from Sphagnum spp. to Ericales shrubs (Ind3) or by an appearance of lichens and dry bryophyte taxa (Kev BS; Fig. 3). Additional testate amoeba data from

341 Seida, Russia also repeat this pattern (Fig. S1). Chronologically, this habitat change corresponds to 342 extensive permafrost degradation reported for the last $c a$. 50 years elsewhere (Sannel and Kuhry, 2011; 343 Swindles et al., 2015a). Local instrumental temperature data from both regions show increasing mean 344 annual temperatures in recent decades (Bekryaev et al., 2010; Bulygina and Razuvaev, 2012; Mikkonen 345 et al., 2015) and warming is projected to continue (Collins et al., 2013). This may have two-fold 346 consequences for permafrost peatlands: accelerated wetting due to thawing of permafrost but followed 347 by desiccation afterwards due to draining and/or an increase in evapotranspiration. Such dynamics were recorded in Ind1 and Ind2 for the recent period, where permafrost thawing caused wet $S$. majus and $S$. rubellum establishment, which were later replaced by dry S. fuscum. The final permafrost degradation could lead to a formation of a northern fen-type environment (Swindles et al. 2015a), but only of the surface falls in surface height further as a result of loss of ice.

\section{Conclusions}

354 Our study emphasises the complex nature and variable sensitivity of permafrost peatlands even within a 355 single site, and highlights the need for a multiproxy approach to environmental change reconstructions. 356 Although hydrological and vegetation reconstructions of six cores showed some core-specific dynamics, 357 when put together our data suggest that in general, LIA conditions were dry, supporting hummocky 358 conditions on top of permafrost. Furthermore, we infer that conspicuous short wet events occurred as a 359 result of the MCA and recent warming, which triggered permafrost thawing. However, some of the 360 hydrological conditions during the MCA were drier than those of during the LIA and recent warming is 361 associated with drier conditions across all sites even where thawing initially led to wetter conditions. The 362 changes towards drier conditions during both the MCA and over the last 150 years suggest that evapotranspiration is an important factor in regulating surface peatland moisture conditions during warm 
periods in the subarctic.

365 The hydrological changes during the most recent warming led to especially pronounced drying of the peat surfaces following thawing, even where initial thaw caused temporarily wetter surfaces. We suggest that drying is more likely to occur where limited permafrost is present, because initial increased surface wetness caused by thawing and surface collapse will be relatively minor, and can revert to drier conditions driven by increased evapotranspiration. Whilst it is likely that continued future warming will result in extensive permafrost degradation and subseqent increased surface wetness and Arctic fen development at the landscape-level, our data show that permafrost peatland ecosystems may also respond in more complex ways, including drying. Future changes in precipitation and evapotranspiration are more uncertain than temperature rise, but may be critical in determinng future hydrology and vegetation shifts in permafrost peatlands.

\section{Acknowledgements}

$377 \mathrm{HZ}$ acknowledges the support of the China Scholarship Council for her PhD study (grant no. 378201404910499 ) at the University of Helsinki. Further funding was provided by the Academy of Finland, 379 the University of Helsinki and the Natural Environment Research Council, UK (NERC Standard grant $380 \mathrm{NE} / \mathrm{I012915/1)}$ Nicole Sanderson helped with ${ }^{210} \mathrm{~Pb}$ analyses, Jaakko Leppänen provided cartographical 381 help, Paul Mathijssen, Tiina Ronkainen and Pirita Oksanen assisted with fieldwork, and Jan Weckström identified the diatoms. We thank Tiina Ronkainen for her comments on the early version of the manuscript.

\section{References}

Abbott, B.W., Jones, J.B., Schuur, E.A.G., Chapin III, F.S., Bowden, W.B., Bret-Harte, M.S., Epstein, H.E., Flannigan, M.D., Harms, T.K., Hollingsworth, T.N., Mack, M.C., McGuire, A.D., Natali, S.M., Rocha, A.V., Tank, S.E., Turetsky, M.R., Vonk, J.E., Wickland, K.P., Aiken, G.R., Alexander, H.D., Amon, R.M.W., Benscoter, B.W., Bergeron, Y., Bishop, K., Blarquez, O., Bond-Lamberty, B., Breen, A.L.,

391 Cooper, L.W., Cornelissen, J.H.C., de Groot, W.J., DeLuca, T.H., Dorrepaal, E., Fetcher, N., Finlay, J.C., 392 Forbes, B.C., French, N.H.F., Gauthier, S., Girardin, M.P., Goetz, S.J., Goldammer, J.G., Gough, L., 393 Grogan, P., Guo, L.D., Higuera, P.E., Hinzman, L., Hu, F.S., Hugelius, G., Jafarov, E.E., Jandt, R., 394 Johnstone, J.F., Karlsson, J., Kasischke, E.S., Kattner, G., Kelly, R., Keuper, F., Kling, G.W., Kortelainen, 395 P., Kouki, J., Kuhry, P., Laudon, H., Laurion, I., Macdonald, R.W., Mann, P.J., Martikainen, P.J., 396 McClelland, J.W., Molau, U., Oberbauer, S.F., Olefeldt, D., Paré, D., Parisien, M-A., Payette, S., Peng, 

M., Rogers, B.M., Schädel, C., Schaefer, K., Schmidt, I.K., Shvidenko, A., Sky, J., Spencer, R.G.M., Starr, G., Striegl, R.G., Teisserenc, R., Tranvik, L.J., Virtanen, T., Welker, J.M., Zimov, S., 2016. Biomass offsets little or none of permafrost carbon release from soil, streams, and wildfire: an expert assessment. Environ. Res. Lett. 11, doi:10.1088/1748-9326/11/3/034014.

402 Ali, A.A., Ghaleb, B., Garneau, M., Asnong, H., Loisel, J., 2008. Recent peat accumulation rates in 403 minerotrophic peatlands of the Bay James region, Eastern Canada, inferred by ${ }^{210} \mathrm{~Pb}$ and ${ }^{137} \mathrm{Cs}$ radiometric techniques. Appl. Radiat. Isot. 66, 1350-1358. Amesbury, M.J., Swindles, G.T., Bobrov, A., Charman, D.J., Holden, J., Lamentowicz, M., Mallon, G., Mazei, Y., Mitchell, E.A.D., Payne, R.J., Roland, T.P., Turner, T.E., Warner, B.G., 2016. Development of a new pan-European testate amoeba transfer function for reconstructing peatland palaeohydrology. Quat. Sci. Rev. 152, 132-151. Appleby, P.G., Oldfield, F., 1978. The calculation of ${ }^{210} \mathrm{~Pb}$ dates assuming a constant rate of supply of unsupported ${ }^{210} \mathrm{~Pb}$ to the sediment. Catena $5,1-8$.

411 Barnett, R.L., Charman, D.J., Gehrels, W.R., Saher, M.H., Marshall, W.A., 2013. Testate amoebae as sea412 level indicators in Northwestern Norway: developments in sample preparation and analysis. Acta 413 Protozool. 52, 115-128.

414 Bekryaev, R.V., Polyakov, I., Alexeev, V.A., 2010. Role of polar amplification in long-term surface air 415 temperature variations and modern arctic warming. J. clim. 23, 3888-3906.

416 Blaauw, M., 2010. Methods and code for 'classical' age-modelling of radiocarbon sequences. Quat. 417 Geochronol. 5, 512-518.

418 Booth, R.K., Lamentowicz, M., Charman, D.J., 2010. Preparation and analysis of testate amoebae in 419 peatland palaeoenvironmental studies. Mires and Peat 7, 1-7.

420 Bosio, J., Johansson, M., Callaghan, T.V., Johansen, B., Christensen, T.R., 2012. Future vegetation 421 changes in thawing subarctic mires and implications for greenhouse gas exchange-a regional assessment. 422 Clim. Change 115, 379-398.

423 Brown, J., Ferrians, O.J., Jr., Heginbottom, J.A., Melnikov, E.S., 1998. revised February 2001. Circum424 arctic map of permafrost and ground ice conditions. Boulder, CO: National Snow and Ice Data Center. 425 Digital media.

426 Brown, J., Romanovsky, V.E., 2008. Report from the International Permafrost Association: State of 427 Permafrost in the First Decade of the $21^{\text {st }}$ Century. Permafrost Periglacial Process. 19, 255-260.

428 Bulygina, O.N., Razuvaev, V.N., 2012. Daily temperature and precipitation data for 518 Russian 429 meteorological stations, Carbon Dioxide Information Analysis Center, Oak Ridge National Laboratory, 
431 Carroll, P., Crill, P., 1997. Carbon balance of a temperate poor fen. Glob. Biogeochem. Cycle 11, 349432356.

433 Charman, D.J., Beilman, D.W., Blaauw, M., Booth, R.K., Brewer, S., Chambers, F.M., Christen, J.A., 434 Gallego-Sala, A., Harrison, S.P., Hughes, P.D.M., Jackson, S.T., Korhola, A., Mauquoy, D., Mitchell, 435 F.J.G., Prentice, I.C., van der Linden, M., De Vleeschouwer, F., Yu, Z.C., Alm, J., Bauer, I.E., Corish, 436 Y.M.C., Garneau, M., Hohl, V., Huang, Y., Karofeld, E., Le Roux, G., Loisel, J., Moschen, R., Nichols, 437 J.E., Nieminen, T.M., MacDonald, G.M., Phadtare, N.R., Rausch, N., Sillasoo, U., Swindles, G.T., 438 Tuittila, E.S., Ukonmaanaho, L., Väliranta, M., van Bellen, S., van Geel, B., Vitt, D.H., Zhao, Y., 2013. 439 Climate-related changes in peatland carbon accumulation during the last millennium. Biogeosciences 10, $440 \quad 929-944$.

441 Charman, D.J., Blundell, A., ACCROTELM members., 2007. A new European testate amoebae transfer 442 function for palaeohydrological reconstruction on ombrotrophic peatlands. J. Quat. Sci. 22, 209-221.

443 Charman, D.J., Blundell, A., Chiverrell, R.C., Hendon, D., Langdon, P.G., 2006. Compilation of non444 annually resolved Holocene proxy climate records: stacked Holocene peatland palaeo-water table 445 reconstructions from northern Britain. Quat. Sci. Rev. 25, 336-350.

446 Charman, D.J., Gehrels, W.R., Manning, C., Sharma, C., 2010. Reconstruction of recent sea-level change using testate amoebae. Quat. Res. 73, 208-219.

448 Charman, D.J., Hendon, D., Woodland, W.A., 2000. The Identification of Testate Amoebae (Protozoa: 449 Rhizopoda) in Peats. Quaternary Research Association, Oxford.

450 Collins, M., Knutti, R., Arblaster, J., Dufresne, J-L., Fichefet, T., Friedlingstein, P., Gao, X., Gutowski, 451 W.J., Johns, T., Krinner, G., Shongwe, M., Tebaldi, C., Weaver, A.J., Wehner, M., 2013. Long-term 452 Climate Change: Projections, Commitments and Irreversibility, In: Stocker, T.F., Qin, D., Plattner, G-K., 453 Tignor, M., Allen, S.K., Boschung, J., Nauels, A, Xia, Y., Bex, V., Midgley, P.M. (Eds.), Climate Change 454 2013: The Physical Science Basis. Contribution of Working Group I to the Fifth Assessment Report of 455 the Intergovernmental Panel on Climate Change. Cambridge University Press, Cambridge, United 456 Kingdom and New York, NY, USA.

457 Cook, E.D., Esper, J., D’Arrigo, R.D., 2004. Extra-tropical Northern Hemisphere land temperature 458 variability over the past 1000 years. Quat. Sci. Rev. 23, 2063-2074.

459 Davidson, E.A., Janssens, I.A., 2006. Temperature sensitivity of soil carbon decomposition and 460 feedbacks to climate change. Nature 440, 165-173.

461 Dorrepaal, E., Toet, S., van Logtestijn, R.S.P., Swart, E., van de Weg, M.J., Callaghan, T.V., Aerts, R., 462 2009. Carbon respiration from subsurface peat accelerated by climate warming in the subarctic. Nature 
$460,616-619$.

464 Esper, J., Cook, E.R., Schweingruber, F.H., 2002. Low-frequency signals in long tree-ring chronologies

465 for reconstructing past temperature variability. Science 295, 2250-2253.

466 Frolking, S., Roulet, N.T., 2007. Holocene radiative forcing impact of northern peatland carbon 467 accumulation and methane emissions. Glob. Change Biol. 13, 1079-1088.

468 Gałka, M., Szal, M., Watson, E.J., Gallego-Sala, A., Amesbury, M.J., Charman, D.J., Roland, T.P., 469 Turner, T.E., Swindles, G.T., 2017a. Vegetation Succession, Carbon Accumulation and Hydrological Change in Subarctic Peatlands, Abisko, Northern Sweden. Permafrost Periglacial Process. doi: 10.1002/ppp.1945.

Gałka, M., Tobolski, K., Górska, A., Lamentowicz, M., 2017b. Resilience of plant and testate amoeba communities after climatic and anthropogenic disturbances in a Baltic bog in Northern Poland: Implications for ecological restoration. Holocene 27, 130-141.

Gałka, M., Tobolski, K., Górska， A., Milecka, K., Fiałkiewicz-Kozieł, B., Lamentowicz, M., 2014. Disentangling the drivers for the development of a Baltic bog during the Little Ice Age in northern Poland. Quat. Int. 328-329, 323-337.

478 Hanhijärvi, S., Tingley, M.P., Korhola, A., 2013. Pairwise comparisons to reconstruct mean temperature in the Arctic Atlantic Region over the last 2,000 years. Clim. Dyn. 41, 2039-2060.

Holmquist, J.R., Finkelstein, S.A., Garneau, M., Massa, C., Yu, Z.C., MacDonald, G.M., 2016. A comparison of radiocarbon ages derived from bulk peat and selected plant macrofossils in basal peat cores from circum-arctic peatlands. Quat. Geochronol. 31, 53-61.

483 Hugelius, G., Routh, J., Kuhry, P., Crill, P., 2012. Mapping the degree of decomposition and thaw remobilization potential of soil organic matter in discontinuous permafrost terrain. J. Geophys. Res. 117, G02030, doi:10.1029/2011JG001873.

IPCC, 2013. Summary for Policymakers, In: Stocker, T.F., Qin, D., Plattner, G-K., Tignor, M., Allen, 487 S.K., Boschung, J., Nauels, A, Xia, Y., Bex, V., Midgley, P.M. (Eds.), Climate Change 2013: The Physical 488 Science Basis. Contribution of Working Group I to the Fifth Assessment Report of the Intergovernmental Panel on Climate Change. Cambridge University Press, Cambridge, United Kingdom and New York, NY, USA.

491 Johansson, M., Åkerman, J., Keuper, F., Christensen, T.R., Lantuit, H., Callaghan, T.V., 2011. Past and 492 present permafrost temperatures in the Abisko Area: redrilling of boreholes. Ambio 40, 558-565.

493 Juggins, S., 2015. Rioja: Analysis of Quaternary ScienceData, R package version (0.9-5). (http://cran.r494 project.org/package=rioja). 
2016. Diatom blooms and associated vegetation shifts in a subarctic peatland: responses to distant volcanic eruptions? J. Quat. Sci. 31, 723-730.

498 Kokfelt, U., Struyf, E., Randsalu, L., 2009. Diatoms in peat-Dominant producers in a changing environment? Soil Biol. Biochem. 41, 1764-1766.

500 Koven, C.D., Ringeval, B., Friedlingstein, P., Ciais, P., Cadule, P., Khvorostyanov, D., Krinner, G.,

501 Tarnocai, C., 2011. Permafrost carbon-climate feedbacks accelerate global warming. Proc. Natl. Acad.

502 Sci. U.S.A. 108, 14769-14774.

503 Lamarre, A., Garneau, M., Asnong, H., 2012. Holocene paleohydrological reconstruction and carbon

504 accumulation of a permafrost peatland using testate amoeba and macrofossil analyses, Kuujjuarapik,

505 subarctic Quebec, Canada. Rev. Palaeobot. Palynology 186, 131-141.

506 Loisel, J., Garneau, M., 2010. Late Holocene paleoecohydrology and carbon accumulation estimates

507 from two boreal peat bogs in eastern Canada: Potential and limits of multi-proxy archives. Paleogeogr.

508 Paleoclimatol. Paleoecol. 291, 493-533.

509 Loisel, J., Yu, Z.C., 2013. Recent acceleration of carbon accumulation in a boreal peatland, south central

510 Alaska. J. Geophys. Res. Biogeosci. 118, 41-53.

511 Masson-Delmotte, V., Schulz, M., Abe-Ouchi, A., Beer, J., Ganopolski, A., González Rouco, J.F., Jansen,

512 E., Lambeck, K., Luterbacher, J., Naish, T., Osborn, T., Otto-Bliesner, B., Quinn, T., Ramesh, R., Rojas,

513 M., Shao, X., Timmermann, A., 2013. Information from Paleoclimate Archives, In: Stocker, T.F., Qin,

514 D., Plattner, G-K., Tignor, M., Allen, S.K., Boschung, J., Nauels, A, Xia, Y., Bex, V., Midgley, P.M. (Eds.),

515 Climate Change 2013: The Physical Science Basis. Contribution of Working Group I to the Fifth

516 Assessment Report of the Intergovernmental Panel on Climate Change. Cambridge University Press,

517 Cambridge, United Kingdom and New York, NY, USA.

518 Mathijssen, P.J.H., 2016. Holocene carbon dynamics and atmospheric radiative forcing of different types 519 of peatlands in Finland. PhD thesis, Dep. Of Environ. Sci., Univ. of Helsinki, Finland. [Available at 520 http://hdl.handle.net/10138/161250.]

521 Mathijssen, P.J.H., Kähkölä, N., Tuovinen, J-P., Lohila, A., Minkkinen, K., Laurila, T., Väliranta, M., 522 2017. Lateral expansion and carbon exchange of a boreal peatland in Finland resulting in 7000 years of 523 positive radiative forcing. J. Geophys. Res. Biogeosci., doi: 10.1002/2016JG003749.

524 Mikkonen, S., Laine, M., Mäkelä, H.M., Gregow, H., Tuomenvirta, H., Lahtinen, M., Laaksonen, A., 525 2015. Trends in the average temperature in Finland, 1847-2013. Stoch. Environ. Res. Risk Assess., 29, 526 1521-1529.

527 Oksanen, P.O., 2006. Holocene development of the Vaisjeaggi palsa mire, Finnish Lapland. Boreas 35, $528 \quad 81-95$. 
Oksanen, P.O., Kuhry, P., Alekseeva, R.N., 2001. Holocene development of the Rogovaya River peat

530 plateau, European Russian Arctic. Holocene 11, 25-40.

531 Ovenden, L., 1990. Peat accumulation in Northern wetlands. Quat. Res. 33, 377-386.

532 Pelletier, N., Talbot, J., Olefeldt, D., Turetsky, M., Blodau, C., Sonnentag, O., Quinton, W.L., 2017.

533 Influence of Holocene permafrost aggradation and thaw on the paleoecology and carbon stirage of a

534 peatland complex in northwestern Canada. Holocene, doi: 10.1177/0959683617693899.

535 Pirinen, P., Simola, H., Aalto, J., Kaukoranta, J-P., Karlsson, P., Ruuhela, R., 2012. Tilastoja Suomen

536 ilmastosta 1981-2010 (Climatological statistics of Finland 1981-2010). Finnish Meteorological Institute

537 Reports, 1.

538 R Core Team, 2014. R: A language and environment for statistical computing. R Foundation for

539 Statistical Computing, Vienna, Austria. URL http://www.R-project.org/.

540 Reimer, P.J., Bard, E., Bayliss, A., Beck, J.W., Blackwell, P.G., Ramsey, C.B., Buck, C.E., Cheng, H.,

541 Edwards, R.L., Friedrich, M., Grootes, P.M., Guilderson, T.P., Haflidason, H., Hajdas, I., Hatté, C.,

542 Heaton, T.J., Hoffmann, D.L., Hogg, A.G., Hughen, K.A., Kaiser, K.F., Kromer, B., Manning, S.W., Niu,

543 M., Reimer, R.W., Richards, D.A., Scott, E.M., Southon, J.R., Staff, R.A., Turney, C.S.M., van der Plicht,

544 J., 2013. IntCal13 and Marine13 radiocarbon age calibration curves, 0-50,000 years cal BP. Radiocarbon

$545 \quad 55,1869-1887$.

546 Repo, M.E., Susiluoto, S., Lind, S.E., Jokinen, S., Elsakov, V., Biasi, C., Virtanen, T., Martikainen, P.j.,

547 2009. Large $\mathrm{N}_{2} \mathrm{O}$ emissions from cryoturbated peat soil in tundra. Nat. Geosci. 2, 189-192.

548 Routh, J., Hugelius, G., Kuhry, P., Filley, T., Tillman, P.K., Becher, M., Crill, P., 2014. Multi-proxy study

549 of soil organic matter dynamics in permafrost peat deposits reveal vulnerability to climate change in the

550 European Russian Arctic. Chem. Geol. 368, 104-117.

551 Sannel, A.B.K., Hugelius, G., Jansson, P., Kuhry, P., 2016. Permafrost warming in a Subarctic peatland-

552 which meteorological controls are most important? Permafrost Periglacial Process. 27. 177-188.

553 Sannel, A.B.K., Kuhry, P., 2011. Warming-induced destabilization of peat plateau/thermokarst lake

554 complexes. J. Geophys. Res. Biogeosci. 116, G03035, doi:10.1029/2010JG001635.

555 Schadel, C., Bader, M.K.F., Schuur, E.A.G., Biasi, C., Bracho, R., Capek, P., De Baets, S., Diakova, K.,

556 Ernakovich, J., Estop-Aragones, C., Graham, D.E., Hartley, I.P., Iversen, C.M., Kane, E.S., Knoblauch,

557 C., Lupascu, M., Martikainen, P.J., Natali, S.M., Norby, R.J., O'Donnell, J.A., Chowdhury, T.R.,

558 Santruckova, H., Shaver, G., Sloan, V.L., Treat, C.C., Turetsky, M.R., Waldrop, M.P., Wickland, K.P.,

559 2016. Potential carbon emissions dominated by carbon dioxide from thawed permafrost soils. Nat. Clim.

560 Chang. 6, 950-954.

561 Schuur, E.A.G., Bockheim, J., Canadell, J.G., Euskirchen, E., Field, C.B., Goryachkin, S.V., Hagemann, 
563 Shiklomanov, N., Tarnocai, C., Venevsky, S., Vogel, J.G., Zimov, S.A., 2008. Vulnerability of Permafrost

564 Carbon to Climate Change: Implications for the Global Carbon Cycle. BioScience 58, 701-714.

565 Swindles, G.T., Morris, P.J., Baird, A.J., Blaauw, M., Plunkett, G., 2012. Ecohydrological feedbacks

566 confound peat-based climate recontructions. Geophys. Res. Lett. 39, doi:10.1029/2012GL051500.

567 Swindles, G.T., Morris, P.J., Mullan, D., Watson, E.J., Turner, T.E., Roland, T.P., Amesbury, M.J., Kokfelt,

568 U., Schoning, K., Pratte, S., Gallego-Sala, A., Charman, D.J., Sanderson, N., Garneau, M., Carrivick,

569 J.L., Woulds, C., Holden, J., Parry, L., Galloway, J.M., 2015a. The long-term fate of permafrost peatlands

570 under rapid climate warming. Sci. Rep. 5, doi: 10.1038/srep17951.

571 Swindles, G.T., Amesbury, M.J., Turner, T.E., Carrivick, J.L., Woulds, C., Raby, C., Mullan, D., Roland,

572 T.P., Galloway, J.M., Parry, L., Kokfelt, U., Garneau, M., Charman, D.J., Holden, J., 2015b. Evaluating

573 the use of testate amoebae for palaeohydrological reconstruction in permafrost peatlands. Paleogeogr.

574 Paleoclimatol. Paleoecol. 424, 111-122.

575 Swindles, G.T., Holden, J., Raby, C.L., Turner, T.E., Blundell, A., Charman, D.J., Menberu, M.W., Kløve,

576 B., 2015c. Testing peatland water-table depth transfer functions using high-resolution hydrological

577 monitoring data. Quat. Sci. Rev. 120, 107-117.

578 Teltewskoi, A., Beermann, F., Beil, I., Bobrov, A., De Klerk, P., Lorenz, S., Luder, A., Michaelis, D.,

579 Joosten, H., 2016. 4000 Years of Changing Wetness in a Permafrost Polygon Peatland (Kytalyk, NE

580 Siberia): A Comparative High-Resolution Multi-Proxy Study. Permafrost Periglacial Process. 27, 76-95.

581 Tremblay, S., Bhiry, N., Lavoie, M., 2014. Long-term dynamics of a palsa in the sporadic permafrost

582 zone of northwestern Quebec (Canada). Can. J. Earth Sci. 51, 500-509.

583 Tuittila, E-S., Juutinen, S., Frolking, S., Väliranta, M., Laine, A.M., Miettinen, A., Seväkivi, M-L.,

584 Quillet, A., Merilä, P., 2012. Wetland chronosequence as a model of peatland development: Vegetation

585 succession, peat and carbon accumulation. Holocene 23, 25-35.

586 University of Leeds Peat Club: Bacon, K.L., Baird, A.J., Blundell, A., Bourgault, M-A., Chapman, P.J.,

587 Dargie, G., Dooling, G.P., Gee, C., Holden, J., Kelly, T., McKendrick-Smith, K.A., Morris, P.J., Noble,

588 A., Palmer, S.M., Quillet, A., Swindles, G.T., Watson, E.J., Young, D.M., 2017. Questioning ten common

589 assumptions about peatlands. Mires Peat 19, 1-23.

590 Väliranta, M., Blundell, A., Charman, D.J., Karofeld, E., Korhola, A., Sillasoo, U., Tuittila, E-S., 2012.

591 Reconstructing peatland water tables using transfer functions for plant macrofossils and testate amoebae:

592 A methodological comparison. Quat. Int. 268, 34-43.

593 Väliranta, M., Korhola, A., Seppa, H., Tuittila, E.S., Sarmaja-Korjonen, K., Laine, J., Alm, J., 2007.

594 High-resolution reconstruction of wetness dynamics in a southern boreal raised bog, Finland, during the 
595 late Holocene: a quantitative approach. Holocene 17, 1093-1107.

596 Väliranta, M., Salonen, J.S., Heikkila, M., Amon, L., Helmens, K., Klimaschewski, A., Kuhry, P., Kultti,

597 S., Poska, A., Shala, S., Veski, S., Birks, H.H., 2015. Plant macrofossil evidence for an early onset of the

598 Holocene summer thermal maximum in northernmost Europe. Nat. Commun. 6, 6809.

599 Wilson, R., Anchukaitis, Kevin., Briffa, K.R., Büntgen, U., Cook, E., D'Arrigo, R., Davi, N., Esper, J.,

600 Frank, D., Gunnarson, B., Hegerl, G., Helama, S., Klesse, S., Krusic, P.J., Linderholm, H.W., Myglan,

601 V., Osborn, T.J., Rydval, M., Schneider, L., Schurer, A., Wiles, G., Zhang, P., Zorita, E., 2016. Last

602 millennium northern hemisphere summer temperatures from tree rings: Part I: The long term context.

603 Quat. Sci. Rev. 134, 1-18.

604 Wilson, R.M., Fitzhugh, L., Whiting, G.J., Frolking, S., Harrison, M.D., Dimova, N., Burnett, W.C.,

605 Chanton, J.P., 2017. Greenhouse gas balance over thaw-freeze cycles in discontinuous zone permafrost.

606 J. Geophys. Res. Biogeosci. 122, 387-404.

607 Yu, Z.C., Beilman, D.W., Jones, M.C., 2009. Sensitivity of Northern Peatland Carbon Dynamics to 608 Holocene Climate Change, in: Baird, A.J., Belyea, L.R. Comas, X., Reeve, A.S., Slater, L.D. (Eds.)

609 Carbon Cycling in Northern Peatlands. American Geophysical Union, Washington, D.C.. doi: $610 \quad 10.1029 / 2008 \mathrm{GM} 000822$.

611 Zhang, H, Amesbury, M.J., Ronkainen, T., Charman, D.J., Gallego-Sala, A.V., Väliranta, M., 2016.

612 Testate amoeba as palaeohydrological indicators in the permafrost peatlands of Northeast European

613 Russia and Finnish Lapland. J. Quat. Sci. doi:10.1002/jqs.2970.

614 Zuidhoff, F.S., Kolstrup, E., 2000. Changes in Palsa Distribution in Relation to Climate Change in 615 Laivadalen, Northern Sweden, Especially 1960-1997. Permafrost Periglacial process. 11, 55-69. 